\title{
AUTOMATIC MONITORING OF BODY CONDITION SCORE OF HIGH YIELDING HOLSTEIN COWS USING THREE-DIMENSIONAL IMAGING TECHNIQUE
}

\author{
Indra Eihvalde, Daina Kairisa \\ Latvia University of Agriculture \\ indra.eihvalde@gmail.com,daina.kairisa@1lu.lv
}

\begin{abstract}
Body condition scoring (BCS) refers to the relative amount of subcutaneous body fat or energy reserve in the dairy cow. BCS is an important management tool for maximizing milk production and reproductive efficiency while reducing the incidence of metabolic and other peripartum diseases. The threedimensional BCS camera, made by the Swedish company "DeLaval" was used in the research. This camera is connected to the cow identification system. According to the camera location place, the cow is evaluated 2 to 10 times per day. The obtained information is sent to the computer. DeLaval 3D camera has been developed for three different cow breed types. The research was done at the Latvia University of Agriculture research and study farm "Vecauce" and the results of 10 primiparous and 10 multiparous Holstein breed cows in the robotic voluntary milking system were analysed. The data were collected from February to December 2016. The research shows that milking cow BCS during 120 lactation days was reduced from 3.5 till 2.7 units and the correlation among the parameters average tight $(r=-0.72)$. The research cows were with a high productivity, in 120 lactation days it was $41.7 \mathrm{~kg}$ in average. The largest BCS during 120 lactation days was noticed to primiparous cows and the correlation between the BCS and milk yield was $r=-0.71$. The parameters among older lactation cow BCS and yielding were less $(r=-0.22)$. The fastest increase of all age cows has been in the first lactation month, where the milk yield increase of primiparous cows was $13.5 \%$, but the BCS decrease was $5.7 \%$. The milk yield increase of multiparous cows was $10 \%$, but the BCS decrease was $5.7 \%$. Primiparous cows, which become pregnant in the first insemination time, were inseminated in the $89 \pm 8.9$ day and their BCS was $3.0 \pm 0.12$ units. Multiparous cows, which become pregnant, were inseminated in the $84 \pm 3.5$ lactation day and their BCS was $2.7 \pm 0.3$ units.
\end{abstract}

Key words: dairy cows, body condition score, milk yield, reproduction.

\section{Introduction}

The determination of the body condition of dairy cows is very important regarding the fertility [1], health and production of the animal [2]. Commonly used methods to estimate fat reserves of cows are the body condition score and backfat thickness. Fat is the most variable component in the body of lactating dairy cows [3]. The proportion of fat deposit is influenced by the nutrition stage of lactation and lactation number. The amount of fat in the body is similar in the first and second lactation, but higher in the third and higher lactation [3]. Control of the BCS is important during the first 120 to 150 days, when there is the largest yielding and insemination of cows takes place [4]. Until now the BCS was evaluated visually, connected with body weight changes. In a mature cow, one body condition score point is equal to $54.4 \mathrm{~kg}$. Dairy cow body condition scoring systems use a 5-point scoring method with quarter-point increments. This system concentrates its accuracy toward the mid-range scores (2.50 to 4.00), which includes most cows. Scores outside this range indicate significant problems, 1.00 denotes a very thin cow, while 5.00 indicates an excessively fat cow [5].

The visual evaluation method has deficiency, such as subjective evaluation, difference among evaluators, evaluation is done rare, as a result it is impossible to notice the largest changes of the cows' BCS. These methods are subjected to restrictions regarding the objectivity of the results and the amount of work. Therefore, a visual three-dimensional sensor system has been developed for automatic determination of the body condition of cows during lactation. The three-dimensional BCS camera, made by the Swedish company "DeLaval", was used in the research.

The aim of the study was to analyse the dairy cow body condition score and the parameters of yielding during the first 120 lactation days.

\section{Materials and Methods}

The research study lasted from February to December of 2016, in a dairy farm with 600 cows in a loose housing system, where 500 cows are milked in a parallel milking parlour and 100 cows are milked in the robot voluntary milking system (VMS) by two robots. The data were obtained from 10 first lactations and 10 multiparous (2-5 lactation) Holstein dairy cows within 120 days after calving. 
The investigated cows were in the robotic milking group, and they were fed by partly mixed rate (PMR), but they got concentrates in the milking robots and food stations.

The body condition was evaluated by using the three-dimensional camera (3D camera), which is installed before the selection gates of the robotic voluntary milking system. The body condition scoring system was evaluated for each cow individually, it depends on how many times the cow went through the selection gates during the day, and the average value was calculated. The milk yield was collected automatically in every milking time and it is counted together in twenty four hours. The results were sent to the Delpro system to record the scale. The milk yield is fixed in the robotic voluntary milking system, but the milk content is not analysed, therefore the milk content traits (milk yield, fat and protein content) were obtained from 4 recordings. Body weight of cows after calving was established during five days by using a verified measuring-tape. Insemination age and the number of the first service in 120 day interval were fixed to the research cows.

The Arithmetic Mean and the Standard Error were the indicators of descriptive statistics applied for the analysis of the obtained data. The single factor disperse analysis was applied to establish the factors affecting the research results. The linear correlation coefficient was used for profiling the interrelations among the results obtained in the study.

\section{Results and Discussion}

Low positive relationship between the BCS and body weight was observed, primiparous cows 0.27 , multiparous cows -0.24 . The average calving BCS was significantly different to primiparous and multiparous cows, respectively $3.5 \pm 0.06$ un $3.1 \pm 0.08(p<0.05)$. In the first 120 lactation days the negative linear correlation between the BCS and milk yield was noticed to all lactation cows, primiparous cows, $r=-0.89$ and multiparous cows, $r=-0.87$ (Fig. 1).

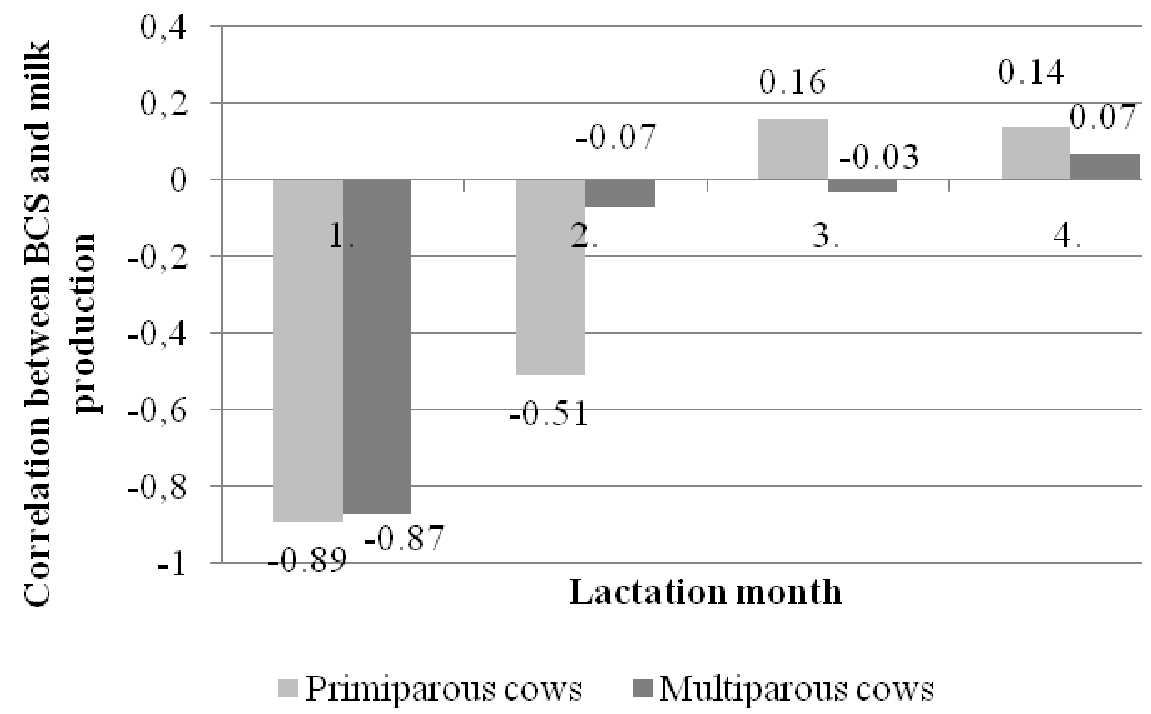

Fig. 1. Correaltin between BCS and milk yield

The negative correlation between both parameters decreased during the second lactation of primiparous cows, $r=-0.51$, but for multiparous cows it was not noticed. In the third month the correlation between the milk yield and BCS was low positive of primiparous cows $(r=0.16)$, but for multiparous cows there was a negative correlation. In the forth lactation month the low positive correlation was noticed between the BCS and milk yield to all lactation cows. The highest milk yield increase and BCS decrease were noticed to all age cows in the first lactation month.

The primiparous cow milk yield and BCS changes in the first 120 lactation days are shown in Fig. 2. In calving the average BCS was 3.5 units, the Czech scientist [6] had the same results. The results were similar in researches in Estonia [7], were the average BCS of primiparous cows in lactation was 3.3-3.5 units. In the research the Holstein breed primiparous cows were calving in 23.3 months, which is an optimal calving period [8]. 


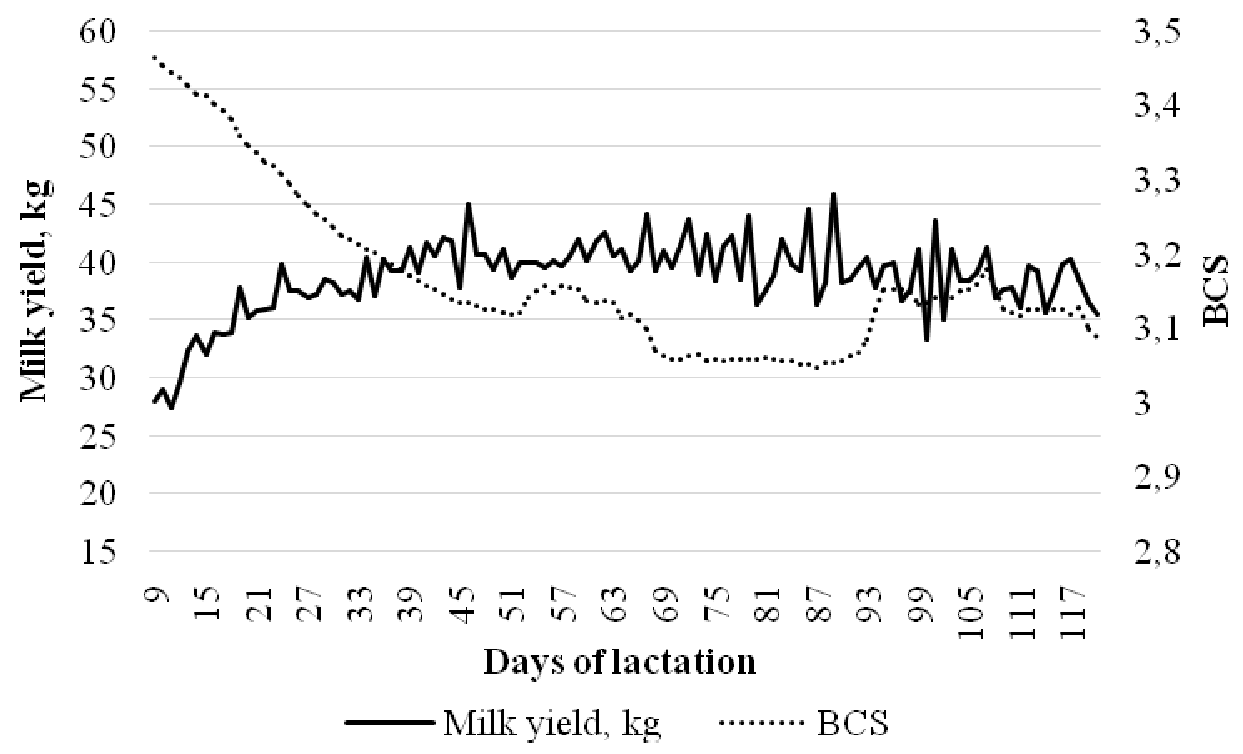

Fig. 2. BCS and milk yield changes of primiparous cows within 120 days of lactation

The BCS decreased essentially from 3.5 units at the beginning of lactation to 3.1 units in 120 lactation days $(p<0.05)$. Other scientists say that BCS decrease has been noticed during the first 3 lactation months $[6 ; 9]$.

The body condition score and milk yield changes for multiparous cows in 120 lactation days are shown in Fig. 3. When lactation started, the multiparous cows were with a significantly lower BCS to compare with primiparous cows $(p<0.05)$. At the beginning of lactation the multiparous cow BCS was 3.1 units, but in 120 lactation days it decreased significantly till 2.7 units $(p<0.05)$.

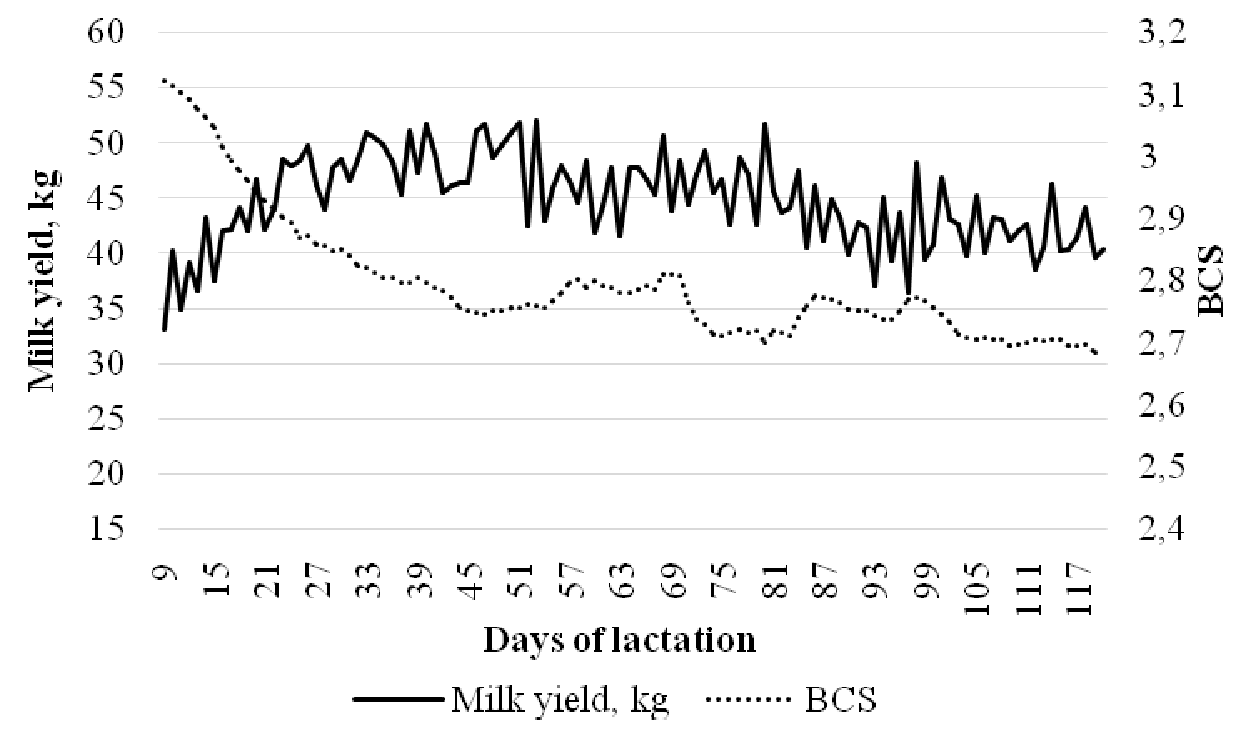

Fig. 3. BCS and milk yield changes of multiparous cows within 120 days of lactation

The research cows were with a high yielding, as other scientists inform - cows with a high yielding have a stress of metabolism, the BCS can decrease because of negative energy balance, it is usually noticed during the first two months [10].

The average BCS and milk yield were calculated for all research cows and it is shown in Fig. 4. The milk yield and BCS in the first 4 lactation months were significantly different to primiparous cows and multiparous cows $(p<0.05)$. 


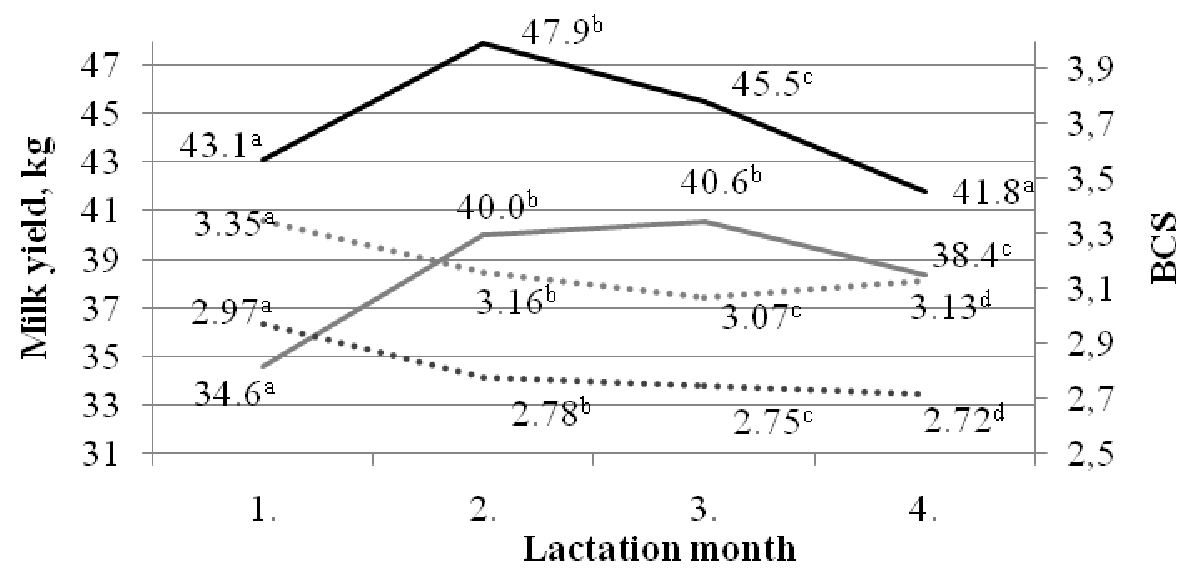

\section{— Milk yield, primiparous cows $\quad$ Milk yield, multiparous cows \\ ..... BCS primiparous cows \\ …... BCS multiparous cows}

Fig. 4. Changes of BCS and milk yield in 4 months:

a,b,c,d - milk yield and BCS across the tested cows are essentially different $(p<0.05)$

The average BCS of primiparous cows in the first lactation month was $3.35 \pm 0.016$ units, the parameter decreased during the second and third month, but the BCS increased a little in the fourth month. The body condition score decreased in the first three lactation months for about 0.28 units. Researches inform, that the BCS cannot decrease for about 1 unit after calving, it can affect insemination and milk yield [7]. The average milk yield of primiparous cows in the first lactation month was $34.6 \pm 0.76 \mathrm{~kg}$ per 24 hours, but the significantly highest milk yield has been reached in the third lactation month, $40.6 \pm 0.45 \mathrm{~kg}(p<0.05)$. The average milk yield of primiparous cows decreased for about $2.2 \mathrm{~kg}$ in the fourth month of lactation. Individually the highest milk yield among primiparous cows has been reached on the 46th lactation day $52.0 \pm 3.64 \mathrm{~kg}$, the cows' BCS was $3.1 \pm 0.07$ units.

The average BCS of multiparous cows in the first lactation month was $2.97 \pm 0.020$ units, it was a significantly lower parameter to compare with primiparous cows $(p<0.05)$. The BCS of multiparous cows decreased for about 0.25 units in the first lactation month. The milk yield of multiparous cows in the first lactation month was $43.1 \pm 1.00 \mathrm{~kg}$, it was significantly higher to compare with primiparous cows $(p<0.05)$. The significantly highest milk yield of multiparous cows has been reached in the second lactation month $47.9 \pm 0.53 \mathrm{~kg}$, but the milk yield significantly decreased in the third and fourth lactation month for about $6.1 \mathrm{~kg}$ in 24 hours $(p<0.05)$. The individually highest milk yield among multiparous cows has been reached on the $53 \mathrm{rd}$ lactation day $52.0 \pm 3.64 \mathrm{~kg}$, the cows' BCS was $2.8 \pm 0.11$ units.

The fastest increase of all age cows has been in the first lactation month, where the milk yield increase of primiparous cows was $13.5 \%$, but the BCS decrease was $5.7 \%$. The milk yield increase of multiparous cows was $10 \%$, but the BCS decrease was $5.7 \%$. By calculating the milk yield changes, the conclusion is that the BCS changes for about 1 unit, the primiparous cow milk yield changed for about $12.1 \mathrm{~kg}$, but for multiparous cows for about $15.9 \mathrm{~kg}$. As a result, it shows that multiparous cows had faster negative energy balance than primiparous cows.

The milk yield fat and protein content in primiparous cow milk in the first 4 recordings are analysed in Table 1. In the first 4 recordings, the protein content in primiparous cow milk was significantly different $(p>0.05)$.

In the first 2 recordings, the protein content in milk did not change practically, but in the 3rd and 4 th recording, it was significantly higher to compare with the first 2 months $(p<0.05)$. Fat and protein ratio in the first two recordings was optimal, but in the third and forth recording the fat and protein ratio shows metabolic acidosis signs. The optimum fat protein ratio is $1.2-1.4$, lower values are likely to lead to subclinical rumen acidosis, which can endanger reproduction performance of cows and enhance a possible development of mineral metabolism disorders. The milk fat and protein ratio higher than 1.4 - signals energy deficit and subclinical ketosis. Czech researchers [11] confirm that the 
fat protein ratio higher than 1.5 can indicate subclinical ketosis, whereas the fat protein ratio lower than 1.1 can mean suspected rumen acidosis.

Table 1

Milk production changes of first 4 recordings of primiparous cows

\begin{tabular}{|c|c|c|c|c|}
\hline Recording & Milk yield, kg & Fat content, \% & $\begin{array}{c}\text { Protein } \\
\text { content, \% }\end{array}$ & $\begin{array}{c}\text { Fat and protein } \\
\text { ratio }\end{array}$ \\
\hline 1. & $36.5 \pm 2.15$ & $3.73 \pm 0.252$ & $3.03 \pm 0.073^{\mathrm{a}}$ & $1.23 \pm 0.072^{\mathrm{a}}$ \\
\hline 2. & $39.8 \pm 1.54$ & $3.60 \pm 0.166$ & $3.00 \pm 0.112^{\mathrm{a}}$ & $1.21 \pm 0.062^{\mathrm{b}}$ \\
\hline 3. & $37.9 \pm 1.29$ & $3.15 \pm 0.337$ & $3.20 \pm 0.119^{\mathrm{b}}$ & $0.99 \pm 0.098^{\mathrm{ca}}$ \\
\hline 4. & $37.9 \pm 1.40$ & $3.49 \pm 0.189$ & $3.25 \pm 0.061^{\mathrm{b}}$ & $1.08 \pm 0.067^{\mathrm{a}}$ \\
\hline \multicolumn{4}{|c|}{} \\
\hline
\end{tabular}

The multiparous cows' milk yield was significantly higher in the 2nd and 3rd recording $(p<0.05)$, the milk parameters are shown in Table 2.

Table 2

Milk production changes of first 4 recordings of multiparous cows

\begin{tabular}{|c|c|c|c|c|}
\hline Recording & Milk yield, kg & Fat content, \% & $\begin{array}{c}\text { Protein } \\
\text { content, \% }\end{array}$ & $\begin{array}{c}\text { Fat and protein } \\
\text { ratio }\end{array}$ \\
\hline 1. & $37.0 \pm 3.35^{\mathrm{a}}$ & $3.50 \pm 0.304$ & $3.14 \pm 0.103$ & $1.10 \pm 0.071^{\mathrm{a}}$ \\
\hline 2. & $50.5 \pm 2.27^{b}$ & $3.50 \pm 0.387$ & $3.00 \pm 0.078$ & $1.16 \pm 0.114^{\mathrm{ab}}$ \\
\hline 3. & $47.4 \pm 1.935^{\mathrm{b}}$ & $3.34 \pm 0.373$ & $3.12 \pm 0.085$ & $1.07 \pm 0.122^{\mathrm{ab}}$ \\
\hline 4. & $42.6 \pm 2.236^{\mathrm{a}}$ & $3.72 \pm 0.190$ & $3.07 \pm 0.071$ & $1.21 \pm 0.589^{\mathrm{b}}$ \\
\hline
\end{tabular}

The fat and protein content in the first 4 recordings has not changed significantly $(p>0.05)$. The fat and protein ratio was lower than expected in the 3rd recording.

High yielding cows should be pregnant up to 120-150 days after calving [12]. By evaluating reproductive performances primiparous cows have been inseminated for the first time on the $91.8 \pm 3.94$ lactation day, when the BCS was $3.08 \pm 0.07$ units, but for multiparous cows $93.8 \pm 5.40$ days, when the BCS was $2.7 \pm 14$ units. Calving to conception interval is significant, primiparous cows, which become pregnant in the first insemination time, were inseminated on the $89 \pm 8.9$ day and their BCS was $3.0 \pm 0.12$ units, primiparous cows' conception rate was $50 \%$. Multiparous cows, which become pregnant, were inseminated on the $84 \pm 3.5$ lactation days and their BCS was $2.7 \pm 0.3$ units, $60 \%$ of them got pregnant. The similar conception rate was in other scientists' researches [13].

\section{Conclusions}

The rerearch demonstrates that during regular BCS decrease, the milk yield and insemination work is noticed, and $50 \%$ primiparous cows and $60 \%$ multiparous cows have been inseminated during the optimal service period. Monitoring the body condition at calving and in early lactation is a useful tool for management of high yielding dairy cows. The three-dimensional BCS camera can save up much information for long term, it serves optimal conclusions about herd management.

\section{References}

1. Buckley F.O., Sullivan K., Mee J.F., Evans R. D., Dillon P. Relationships among milk yield, body condition, cow weight, and reproduction in spring-calving Holstein-Friesians. Journal of Dairy Science, vol. 86 (7), 2003, pp. 2308-2319.

2. Roche J.R., Berry D.P. Periparturient climatic, animal and management factors influencing the incidence of milk fever in grazing systems. Journal of Dairy Science, vol. 89 (7), 2006, pp. 2775- 2783.

3. Yan T., Patterson D., Mayne C., Agnew R., Porter M. Preddiction of empty body weight and compositition from live weight and other live aninal measurements in lactaction dairy cows. Journal of Agricultures Science, vol. 147, 2009, pp. 241-252. 
4. Poncheki J.K., Schultz Canha M.L.,Viechnieski S.L., Almeid R. Analysis of daily body weight of dairy cows in early lactation and associations with productive and reproductive performance. Revista Brasileira de Zootecnia, vol. 44 (5), 2015, pp.187-192.

5. Bewely J., Schuntz M. An Interdisciplinary Review of Body Condition Scoring for Dairy Cattle. The Profesional Animal Scientist, vol. 24, (6), 2008, pp. 507-529.

6. Maršalek, M., Zednikova, J., Pešta, V.,Kubešova, M. Holstein cattle reproduction in relation on milk yield and body condition score, Journal of Central European Agriculture, vol. 9, (4), 2008, pp. 621-628.

7. Samarütel J.,Ling K., Jaakson H., Kaart T., Kärt O. Efect of body condition score at parturition on the production performance, fertility and culling in primiparous Estonian Holstein cows. Veterinaria i zootetechnika, vol. 36 (58), 2006, pp. 69-74.

8. Changhee Do, Wasana N., Cho K., Choi Y., Choi T., Park B., Lee D.. The Effect of Age at First Calving and Calving Interval on Productive Life and Lifetime Profit in Korean Holsteins. Asian-Australas Journal of Animal Science, vol. 26 (11), 2013, pp. 1511-1517.

9. Stadnik L., Louda F., Ježkova A. The eff ect of selected factors at insemination on reproduction of Holstein cows. Czech Journal of Animal Science, vol. 47 (5), 2002, pp. 169-175.

10. Block S.S., Butler W.R., Ehrhardt R.A., Bell A.W., Van Amburgh M.E., Boisclair Y.R. Decreased concentration of plasma leptin in periparturient dairy cows is caused by negative energy balance. Journal of Endocrinology, vol. 171, 2001, pp. 339-348.

11. Čejna V., Chladek G. The importance of monitoring changes in milk fat to milk protein ratio in Holstein cows during lactation. Journal of central European Agriculture, vol. 6, (4), 2005, pp. 539-546.

12. Alawneh J.I., Stevenson M.A., Williamson N.B., Lopez-Vilallobos N., Otley T. The effect of liveweight change on reproductive performance in a seasonally calving, pasture fed dairy herd. Livestock Science, vol 145, 2012, pp. 131-139.

13. Marques M.O., Morotti F., Bizarro da Silva C., Ribeiro M. Júnior, Pinto da Silva R.C., Baruselli P.S., Seneda M.M. Influence of category-heifers, primiparous and multiparous lactating cows-in a large-scale resynchronization fixed-time artificial insemination program. Journal of Veterinary Science, vol. 16 (3), 2015, pp. 367-371. 